\title{
Effect of Brown Manuring and Herbicides on Growth, Nitrogen Uptake and Weed Dynamics in Direct Seeded Rice (Oryza sativa L.)
}

\author{
Sneha Kumari* and Tarundeep Kaur
}

Dept. of Agronomy, Punjab Agricultural University, Ludhiana, Punjab (141 004), India

\section{Article History}

Manuscript No. AR1641

Received in $16^{\text {th }}$ July, 2016

Received in revised form $30^{\text {th }}$ November, 2016

Accepted in final form $2^{\text {nd }}$ November, 2016

\section{Correspondence to}

${ }^{*}$ E-mail: snehak723@gmail.com

\section{Keywords}

Brown manuring, direct seeded rice, herbicides, nitrogen uptake

\begin{abstract}
A field experiment was conducted at Department of Agronomy, PAU, Ludhiana. The twelve treatments were rice sole (without herbicide, pendimethalin $750 \mathrm{~g} \mathrm{ha}^{-1}$ as PRE, bispyribac $25 \mathrm{~g} \mathrm{ha}^{-1}$ as POST and pendimethalin $750 \mathrm{~g} \mathrm{ha}^{-1} \mathrm{fb}$ bispyribac $25 \mathrm{~g}$ $\mathrm{ha}^{-1}$ ), rice + Sesbania (Brown manuring (BM) of Sesbania at 4 WAS, pendimethalin $750 \mathrm{~g} \mathrm{ha}^{-1}$ and BM of Sesbania at 4 WAS, BM of Sesbania at 4 WAS and bispyribac $25 \mathrm{~g} \mathrm{ha}^{-1}$ and pendimethalin $750 \mathrm{~g} \mathrm{ha}^{-1}$ and BM of Sesbania at 4 WAS and bispyribac $25 \mathrm{~g} \mathrm{ha}^{-1}$ ) and rice + Sesbania (BM of Sesbania at 5 WAS, pendimethalin $750 \mathrm{~g} \mathrm{ha}^{-1}$ and BM of Sesbania at 5 WAS, BM of Sesbania at 5 WAS and bispyribac $25 \mathrm{~g}$ $\mathrm{ha}^{-1}$ and pendimethalin $750 \mathrm{~g} \mathrm{ha}^{-1}$ and BM of Sesbania at 5 WAS and bispyribac $25 \mathrm{~g} \mathrm{ha}^{-1}$ ). Rice with Sesbania, knockdown at 4 and 5 WAS recorded less weed density as compared to sole rice. Integrated use of rice+Sesbania (BM of Sesbania

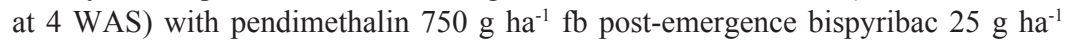
recorded significantly higher biological yield than all other combinations of BM and herbicides. The nitrogen content in paddy grains and straw was not influenced significantly by different brown manuring treatments. $\mathrm{N}$ content and uptake in weeds was significantly higher in sole rice under unsprayed check as compared to all other treatment combinations which were at par with each other. Nitrogen uptake in paddy grains was influenced significantly by different brown manuring treatments which varied from 40.12 to $56.22 \mathrm{~kg} \mathrm{ha}^{-1}$. N uptake in straw was significantly higher with rice+BM (4 WAS) in pendimethalin fb bispyribac.
\end{abstract}

\section{Introduction}

Rice (Oryza sativa L.) is the principal source of food for more than half of the world's population. It is the main staple food crop of India, covering an area of about 44.14 mha with total production of $106.65 \mathrm{mt}$ of rice during 2013-14 (Anonymous, 2016). In Punjab, rice was cultivated on an area of about 2.89 mha with total production of $11.10 \mathrm{mt}$ of rice during 2015 (PAU, 2016). Rice is mainly cultivated by transplanting in puddled field, which results in the formation of hard pan and damages soil structure, though it helps in retention of more water and effective in weed control, but this needs more time, labour and energy. With the advent of resource conserving technologies, direct seeding is being emerged as a viable alternative to transplanted rice (Tripathi et al., 2004). Farmers are keen to adopt direct seeded rice (DSR) instead of transplanted rice as there is acute shortage of labour and sky rocketing wages of labourers in Punjab at the peak transplanting time. Moreover underground water is being depleted due to more requirement of water in puddled transplanted rice. So, an increasing trend has been observed with the farmers for adoption of direct seeded rice instead of transplanted rice. Further, it also shortens the cropping cycle due to absence of transplanting shock to the seedlings. So the adoption of direct seeding of rice is catching the fancy of farmers in Punjab.

Severe infestation of weeds in direct seeded rice is the main problem which causes grain yield loss up to $90 \%$ (Gaire et al., 2013). Uncontrolled weeds reduce the grain yield by $96 \%$ in direct seeded rice, $61 \%$ in wet direct seeded rice and $40 \%$ in transplanted rice (Maity and Mukherjee, 2008). Yield losses ranging from 17 to $24 \%$ were recorded in direct seeded rice when weeds were allowed to compete with rice until 4 weeks after sowing (Chauhan and Johnson, 2011). Season-long weed competition in direct seeded aerobic rice may cause yield reduction up to $80 \%$ (Sunil et al., 2010). Weed infestation may cause complete failure of aerobic rice in extreme cases (Jayadeva et al., 2011). Thus, direct seeded aerobic rice is highly vulnerable to weeds compared with other rice ecosystems (Anwar et al., 2012). 
Weeds are among the major biological constraints for broader adoption of direct seeded rice and therefore, the cultivation of direct seeded rice warrants intensive use of herbicides for weed control (Mahajan and Chauhan, 2013). Herbicides offer the most effective, economical and practical way of weed management. As weed populations are shifted by herbicides, weed formerly of secondary importance emerge as primary weed problems. Such problems may be avoided by an integrated system of weed management. Besides, farmers are now becoming increasingly interested in more inclusive weed management strategy to reduce herbicide dependence (Blackshaw et al., 2005).

Weeds usually take mineral nutrients faster than many of the crop plants and accumulate them in their tissues in relatively larger amount (Das and Yaduraju, 1996). They not only reduce the amount of $\mathrm{N}$ available to the crops but also suppress the crop growth (Blackshaw, 2003). $\mathrm{N}$ application improved the $\mathrm{N}$ uptake by crop plant and ultimately accelerate photosynthetic activities in the plant which results in better growth and development of the crop. Among the plant nutrients nitrogen, phosphorus and potassium are limiting ones and nitrogen is the first nutrient to become limiting due to crop-weed competition. Brown manuring of Sesbania suppressed the weed flora as a result increased the availability of nutrients to the crop thereby reducing the nutrient uptake by weeds and producing better crop yield. Therefore, adoption of integrated weed management (IWM) is essential for weed management in direct seeded rice. In order to devise an integrated weed management strategy for direct seeded rice, studies need to be done on brown manuring in combination with herbicides. Since not much work have been done in this field, this research is designed to address the problem of making direct seeded rice popular among farmers with the objective of evaluating the effect of integrated weed management practices on nutrient uptake in direct seeded rice and weeds.

\section{Materials and Methods}

The field experiment was conducted Students' Research Farm, Department of Agronomy, Punjab Agricultural University, Ludhiana, Punjab during kharif, 2015. The experiment was done in Randomized Complete Block Design by keeping twelve treatments in four replications. The soil of the experimental field was sandy loam. The treatments were comprised of rice sole (without herbicide, pendimethalin $750 \mathrm{~g} \mathrm{ha}^{-1}$ as pre-emergence, bispyribac $25 \mathrm{~g} \mathrm{ha}^{-1}$ as postemergence and pendimethalin $750 \mathrm{~g} \mathrm{ha}^{-1} \mathrm{fb}$ bispyribac $25 \mathrm{~g}$ ha $^{-1}$ ), Rice + Sesbania (Brown manuring (BM) of Sesbania at 4 WAS, pendimethalin $750 \mathrm{~g} \mathrm{ha}^{-1}$ and BM of Sesbania at 4 WAS, BM of Sesbania at 4 WAS and bispyribac $25 \mathrm{~g} \mathrm{ha}^{-1}$ and pendimethalin $750 \mathrm{~g} \mathrm{ha}^{-1}$ and BM of Sesbania at 4 WAS and bispyribac $25 \mathrm{~g} \mathrm{ha}^{-1}$ ) and Rice+Sesbania (BM of Sesbania at 5 WAS, pendimethalin $750 \mathrm{~g} \mathrm{ha}^{-1}$ and BM of Sesbania at 5
WAS, BM of Sesbania at 5 WAS and bispyribac $25 \mathrm{~g} \mathrm{ha}^{-1}$ and pendimethalin $750 \mathrm{~g} \mathrm{ha}^{-1}$ and BM of Sesbania at 5 WAS and bispyribac $25 \mathrm{~g} \mathrm{ha}^{-1}$ ). Rice variety 'PR 115' was sown in the first week of June in $20 \mathrm{~cm}$ row spacing with $20 \mathrm{~kg} \mathrm{ha}^{-1}$ seeding rate. Sesbania was broadcasted @ $25 \mathrm{~kg} \mathrm{ha}^{-1}$ along with rice seeding and it was killed by spraying 2, 4-D amine salt 58\% $\left(580 \mathrm{~g} \mathrm{ha}^{-1}\right)$ at 4 and $5 \mathrm{WAS}$. The herbicides were applied as per the treatment using 500 litres ha ${ }^{-1}$ water with knapsack sprayer fitted with flat-fan nozzle. The crop was raised as per recommended package of practices. The plant height was recorded from each plot from randomly selected five plants. The weeds present inside the randomly placed quadrate were cut at the ground level and then dried in the hot air oven at $60 \pm 2$ ${ }^{\circ} \mathrm{C}$ till constant weight. Samples of rice grain, rice straw and weeds were collected at harvest, dried in sun and then dried in oven at $60^{\circ} \mathrm{C}$ for estimation of nitrogen content. Nitrogen content of grain, straw and weeds were estimated using Micro Kjeldahl's method of Mckenzine and Wallace (1964). All data were analyzed by factorial RBD using the SAS Proc GLM (SAS 9.3). The comparisons were made at 5\% level of significance by using Duncun's Multiple Range Test (DMRT).

\section{Results and Discussion}

Plant height is an important parameter that can be used to study the effect of different treatments on crop growth. Rice sole without $\mathrm{BM}$ recorded significantly less plant height $(80.43 \mathrm{~cm})$ as compared to rice with BM. Among interaction, rice sole without herbicides recorded significantly less plant height $(73.29 \mathrm{~cm})$ as compared with all other treatments. Tiller count unit ${ }^{-1}$ area is an important parameter for determining the effect of any treatment on growth and yield of a cereal crop like rice. At harvest, rice sole without herbicides recorded significantly less tiller count (144) as compared to all other treatments. Rice+BM (4 WAS) with pendimethalin followed by bispyribac recorded the highest tiller count (360) followed by sole rice with pendimethalin fb bispyribac (300) and rice+BM (4 WAS) with pendimethalin alone (289). The total weed density was significantly more in rice without BM than under both rice + BM (4 and 5 WAS). Among herbicide treatments, pendimethalin at $750 \mathrm{~g}$ fb bispyribac sodium at $25 \mathrm{~g} \mathrm{ha}^{-1}$ recorded significantly less weed density as compared to the other herbicide treatments.

The interaction effect of BM and herbicide treatments on weed density was significant. Interaction effect revealed that in all herbicide treatments, rice+BM (4 and 5 WAS) recorded significantly less density of weeds compared to rice without $\mathrm{BM}$, whereas in BM treatments, pendimethalin fb bispyribac sodium plots recorded less density of total weeds compared to pendimethalin alone and bispyribac alone. Unsprayed check recorded significantly more density of total weeds than all other treatment combinations. Significantly less weed density was observed in rice+BM (4 WAS) with pendimethalin $\mathrm{fb}$ 
bispyribac sodium which was closely followed by rice+BM (5 WAS) with pendimethalin fb bispyribac sodium. Weed dry weight data revealed that (Table 1) total weed dry matter accumulation was significantly less in case of rice+BM (4 WAS) as compared to rice without BM but this was at par with $\mathrm{BM}$ rice+BM (5 WAS). Among herbicide treatments,

Table 1: Effect of brown manuring (BM) and herbicide treatments on plant height, number of tillers, total weed density, total weed dry weight and biological yield in direct seeded rice

\begin{tabular}{|c|c|c|c|c|c|}
\hline Treatment & $\begin{array}{l}\text { Plant height } \\
\quad(\mathrm{cm})\end{array}$ & $\begin{array}{l}\text { No. of tillers } \\
\mathrm{m}^{-2}\end{array}$ & $\begin{array}{l}\text { Total weed density } \\
\text { (no. } \mathrm{m}^{-2} \text { ) At harvest }\end{array}$ & $\begin{array}{l}\text { Total weed dry weight } \\
\left(\mathrm{g} \mathrm{m}^{-2}\right) \text { At harvest }\end{array}$ & $\begin{array}{c}\text { Biological } \\
\text { yield }\left(\mathrm{kg} \mathrm{ha}^{-1}\right)\end{array}$ \\
\hline \multicolumn{6}{|l|}{ Brown manuring $(\mathrm{BM})$} \\
\hline Rice sole & $80.43^{\mathrm{b}}$ & $205^{\mathrm{b}}$ & $10.86^{\mathrm{a}}(126)$ & $15.95^{\mathrm{a}}(281)$ & $88.95^{\mathrm{b}}$ \\
\hline Rice+BM (4 WAS) & $84.84^{\mathrm{a}}$ & $270^{\mathrm{a}}$ & $6.92^{\mathrm{b}}(53)$ & $9.97^{b}(112)$ & $118.06^{\mathrm{a}}$ \\
\hline Rice+BM (5 WAS) & $83.59^{\mathrm{a}}$ & $245^{\mathrm{a}}$ & $7.76^{\mathrm{b}}(63)$ & $10.31^{\mathrm{b}}(113)$ & $110.96^{\mathrm{a}}$ \\
\hline \multicolumn{6}{|l|}{ Herbicides } \\
\hline Without herbicides & $80.01^{\mathrm{b}}$ & $187^{\mathrm{c}}$ & $10.46^{\mathrm{a}}(117)$ & $16.40^{\mathrm{a}}(289)$ & $76.08^{d}$ \\
\hline Pendimethalin $750 \mathrm{~g} \mathrm{ha}^{-1}$ & $83.44^{\mathrm{ab}}$ & $252^{\mathrm{b}}$ & $10.04^{a}(105)$ & $11.36^{\mathrm{bc}}(135)$ & $116.70^{\mathrm{b}}$ \\
\hline Bispyribac $25 \mathrm{~g} \mathrm{ha}^{-1}$ & $82.07^{\mathrm{b}}$ & $215^{\mathrm{c}}$ & $8.00^{\mathrm{b}}(67)$ & $12.65^{\mathrm{b}}(164)$ & $96.01^{\mathrm{c}}$ \\
\hline $\begin{array}{l}\text { Pendimethalin } 750 \mathrm{~g} \mathrm{ha}^{-1} \mathrm{fb} \\
\text { Bispyribac } 25 \mathrm{~g} \mathrm{ha}^{-1}\end{array}$ & $86.30^{\mathrm{a}}$ & $308^{\mathrm{a}}$ & $5.56^{\mathrm{c}}(33)$ & $6.31^{\mathrm{d}}(43)$ & $135.13^{\mathrm{a}}$ \\
\hline Interaction & $\mathrm{S}$ & S & $\mathrm{S}$ & S & S \\
\hline
\end{tabular}

Data were subjected to square root transformation $\sqrt{x}_{\mathrm{x}}+1$. Parentheses are original values; In a column, means followed by common letters do not differ significantly at $(p=0.05)$ level by DMRT

dry matter accumulation by weeds was significantly less in pendimethalin fb bispyribac sodium treated plots. Averaged over weed control treatments, biological yield was significantly higher in BM (4 WAS) compared to the BM (5 WAS) and without BM (Table 2). Unsprayed check recorded significantly lower yield as compared to herbicide treatments. Pendimethalin $\mathrm{fb}$ bispyribac sodium recorded significantly higher yield as compared to pendimethalin and bispyribac sodium alone.

Table 2: Effect of brown manuring (BM) and herbicide treatments on $\mathrm{N}$ content and $\mathrm{N}$ uptake of grain, straw and weeds in direct seeded rice

\begin{tabular}{|c|c|c|c|c|c|}
\hline \multicolumn{3}{|c|}{$\mathrm{N}$ content $(\%)$} & \multicolumn{3}{|c|}{$\mathrm{N}$ uptake $\left(\mathrm{kg} \mathrm{ha}^{-1}\right)$} \\
\hline Grain & Straw & Weeds & Grain & Straw & Weeds \\
\hline \multicolumn{6}{|c|}{ Brown manuring } \\
\hline $1.20^{\mathrm{a}}$ & $0.62^{\mathrm{a}}$ & $1.31^{\mathrm{a}}$ & $40.12^{c}$ & $35.25^{\mathrm{b}}$ & $40.66^{\mathrm{a}}$ \\
\hline $1.20^{\mathrm{a}}$ & $0.58^{\mathrm{ab}}$ & $1.12^{\mathrm{b}}$ & $56.22^{\mathrm{a}}$ & $43.27^{\mathrm{a}}$ & $12.68^{\mathrm{b}}$ \\
\hline $1.15^{\mathrm{ab}}$ & $0.62^{\mathrm{a}}$ & $1.33^{\mathrm{a}}$ & $48.04^{\mathrm{b}}$ & $44.47^{\mathrm{a}}$ & $13.03^{b}$ \\
\hline \multicolumn{6}{|c|}{ Herbicides } \\
\hline $1.11^{\mathrm{ab}}$ & $0.58^{\mathrm{b}}$ & $1.36^{\mathrm{a}}$ & $29.86^{\mathrm{d}}$ & $29.17^{\mathrm{c}}$ & $43.44^{\mathrm{a}}$ \\
\hline $1.20^{\mathrm{a}}$ & $0.64^{\mathrm{a}}$ & $1.13^{\mathrm{c}}$ & $53.92^{b}$ & $47.01^{\mathrm{a}}$ & $20.48^{\mathrm{b}}$ \\
\hline $1.18^{\mathrm{ab}}$ & $0.60^{\mathrm{a}}$ & $1.20^{\mathrm{ab}}$ & $41.81^{c}$ & $37.02^{b}$ & $20.12^{\mathrm{b}}$ \\
\hline $1.24^{\mathrm{a}}$ & $0.62^{\mathrm{a}}$ & $1.04^{\mathrm{d}}$ & $66.90^{\mathrm{a}}$ & $50.79^{\mathrm{a}}$ & $4.46^{\mathrm{c}}$ \\
\hline NS & $\mathrm{S}$ & $\mathrm{S}$ & $\mathrm{S}$ & $\mathrm{S}$ & $\mathrm{S}$ \\
\hline
\end{tabular}

In a column, means followed by common letters do not differ significantly at $(p=0.05)$ level by DMRT
Different growth and yield attributing characters viz; plant height and number of tillers significantly lower in case of alone application of bispyribac sodium and pendimethalin, thus resulted in significantly less yield.

Interaction of BM treatments and herbicide treatments clearly revealed that, pendimethalin $750 \mathrm{~g} \mathrm{ha}^{-1} \mathrm{fb}$ bispyribac $25 \mathrm{~g}$ ha $^{-1}$ produced significantly higher yield in BM treatment. Under unsprayed check, BM (5 WAS) recorded significantly higher yield as compared to BM (4 WAS) and without BM in unsprayed check, whereas, it was at par with the yield of pendimethalin $750 \mathrm{~g} \mathrm{ha}^{-1}$ without BM and bispyribac $25 \mathrm{~g} \mathrm{ha}^{-1}$ with BM (4 and 5 WAS). Under pendimethalin $750 \mathrm{~g} \mathrm{ha}^{-1}$, BM (4 WAS) recorded significantly higher yield as compared to other BM treatments. Application of bispyribac $25 \mathrm{~g} \mathrm{ha}^{-1}$ with BM (4 WAS) recorded significantly higher yield than without BM and at par with BM (5 WAS) combination that was similar with the pattern shown by the grain yield of rice+BM (4 WAS) with pendimethalin $750 \mathrm{~g} \mathrm{ha}^{-1} \mathrm{fb}$ bispyribac $25 \mathrm{~g} \mathrm{ha}^{-1}$ recorded highest yield followed by with the combination of same herbicidal treatment with BM (5 WAS) and without BM which were at par with each other.

Nitrogen is an integral part of different enzymes, proteins and chlorophyll etc. The data of nitrogen content of paddy grain as presented in Table 3 revealed that nitrogen content in paddy grains was not influenced significantly by different brown manuring treatments and it varied from 1.15 to $1.20 \%$. Similarly, different herbicide treatments failed to exhibit any 
Table 3: Interaction effect of brown manuring (BM) and herbicide treatments on plant height $(\mathrm{cm})$ and no. of tillers $\mathrm{m}^{-2}$ in direct seeded rice

\begin{tabular}{|c|c|c|c|c|c|c|}
\hline \multirow[t]{2}{*}{ Treatment } & \multicolumn{3}{|c|}{ Plant height } & \multicolumn{3}{|c|}{ No. of tillers $\mathrm{m}^{-2}$} \\
\hline & Rice sole & $\begin{array}{c}\text { Rice+BM } \\
\text { (4 WAS) }\end{array}$ & $\begin{array}{l}\text { Rice+BM } \\
\text { (5 WAS) }\end{array}$ & Rice sole & $\begin{array}{l}\text { Rice+BM } \\
\text { (4 WAS) }\end{array}$ & $\begin{array}{l}\text { Rice+BM } \\
\text { (5 WAS) }\end{array}$ \\
\hline Without herbicides & $73.29^{c}$ & $83.97^{\mathrm{ab}}$ & $82.78^{\mathrm{ab}}$ & $144^{\mathrm{f}}$ & $186^{\mathrm{ef}}$ & $230^{\text {de }}$ \\
\hline Pendimeth-alin $750 \mathrm{~g} \mathrm{ha}^{-1}$ & $81.84^{\mathrm{b}}$ & $84.62^{\mathrm{a}}$ & $83.85^{\mathrm{ab}}$ & $218^{\mathrm{de}}$ & $289^{\mathrm{bc}}$ & $248^{\text {bcd }}$ \\
\hline Bispyribac $25 \mathrm{~g} \mathrm{ha}^{-1}$ & $79.93^{\mathrm{b}}$ & $82.85^{\mathrm{ab}}$ & $83.46^{\mathrm{ab}}$ & $159^{\mathrm{f}}$ & $248^{\text {bcd }}$ & $240^{\mathrm{cd}}$ \\
\hline $\begin{array}{l}\text { Pendimeth-alin } 750 \mathrm{~g} \mathrm{ha}^{-1} \\
\mathrm{fb} \text { Bispyribac } 25 \mathrm{~g} \mathrm{ha}^{-1}\end{array}$ & $86.68^{\mathrm{a}}$ & $87.94^{\mathrm{a}}$ & $84.27^{\mathrm{ab}}$ & $300^{\mathrm{b}}$ & $360^{\mathrm{a}}$ & $264^{\text {bcd }}$ \\
\hline
\end{tabular}

Means followed by common letters do not differ significantly at $(p=0.05)$ level by DMRT

significant effect on nitrogen content of paddy grains. The range of numerical values ranged from 1.11 to $1.24 \%$. The data with respect of nitrogen content to paddy straw is presented in Table 4. It can be concluded from the data that different brown manuring treatments did not have any significant effect on nitrogen content of paddy straw. Numerically, the nitrogen content of paddy straw varied from 0.58 to $0.62 \%$. However, different herbicide treatments influence the nitrogen

Table 4: Interaction effect of brown manuring (BM) and herbicide treatments on total weed density $\left(\mathrm{No}^{-2} \mathrm{~m}^{-2}\right.$ and total weed dry matter $\left(\mathrm{g} \mathrm{m}^{-2}\right)$ at harvest in direct seeded rice

\begin{tabular}{|c|c|c|c|c|c|c|}
\hline \multirow[t]{2}{*}{ Treatment } & \multicolumn{3}{|c|}{ Total weed density } & \multicolumn{3}{|c|}{ Total weed dry matter } \\
\hline & $\begin{array}{l}\text { Rice } \\
\text { sole }\end{array}$ & $\begin{array}{l}\text { Rice+BM } \\
\text { (4 WAS) }\end{array}$ & $\begin{array}{c}\text { Rice+BM } \\
\text { (5 WAS) }\end{array}$ & $\begin{array}{l}\text { Rice } \\
\text { sole }\end{array}$ & $\begin{array}{l}\text { Rice+BM } \\
\text { (4 WAS) }\end{array}$ & $\begin{array}{c}\text { Rice+BM } \\
\text { (5 WAS) }\end{array}$ \\
\hline Without herbicides & $22.62^{\mathrm{a}}(511)$ & $14.33^{\mathrm{c}}(206)$ & $12.28^{\mathrm{d}}(150)$ & $14.07^{\mathrm{a}}(200)$ & $8.95^{\mathrm{cd}}(80)$ & $8.36^{\mathrm{cd}}(71)$ \\
\hline Pendimethalin $750 \mathrm{~g} \mathrm{ha}^{-1}$ & $16.50^{\mathrm{c}}(273)$ & $10.48^{\mathrm{e}}(110)$ & $10.12^{\mathrm{d}}(100)$ & $11.98^{\mathrm{ab}}(145)$ & $8.63^{\mathrm{cd}}(73)$ & $9.88^{\mathrm{bc}}(97)$ \\
\hline Bispyribac $25 \mathrm{~g} \mathrm{ha}^{-1}$ & $17.20^{\mathrm{b}}(295)$ & $10.52^{\mathrm{e}}(111)$ & $10.23^{\mathrm{e}}(105)$ & $10.23^{\text {bc }}(107)$ & $6.71^{\text {de }}(45)$ & $7.08^{\mathrm{de}}(50)$ \\
\hline $\begin{array}{l}\text { Pendimethalin } 750 \mathrm{~g} \mathrm{ha}^{-1} \mathrm{fb} \\
\text { Bispyribac } 25 \mathrm{~g} \mathrm{ha}^{-1}\end{array}$ & $8.12^{\mathrm{f}}(66)$ & $4.55^{\mathrm{h}}(21)$ & $6.25^{\mathrm{g}}(40)$ & $7.16^{\text {de }}(53)$ & $3.78^{\mathrm{f}}(14)$ & $5.74^{\mathrm{ef}}(33)$ \\
\hline
\end{tabular}

Means followed by common letters do not differ significantly at $(p=0.05)$ level by DMRT; Data were subjected to square root transformation $\sqrt{x}+1$. Parentheses are original values.

content of paddy straw. $\mathrm{N}$ content in straw in pendimethalin $\mathrm{fb}$ bispyribac sodium, pendimethalin alone and bispyribac alone were statically at par with each other but significantly higher than unsprayed check. The data embodied in Table 5 revealed that nitrogen content (\%) in weeds was affected

Table 5 Interaction effect of brown manuring (BM) and herbicide treatments on biological yield $\left(\mathrm{kg} \mathrm{ha}^{-1}\right)$ in direct seeded rice

\begin{tabular}{lccc}
\hline Treatment & \multicolumn{3}{c}{ Biological yield $\left(\mathrm{kg} \mathrm{ha}^{-1}\right)$} \\
\cline { 2 - 4 } & $\begin{array}{c}\text { Rice } \\
\text { sole }\end{array}$ & $\begin{array}{c}\text { Rice }+\mathrm{BM} \\
(4 \mathrm{WAS})\end{array}$ & $\begin{array}{c}\text { Rice }+\mathrm{BM} \\
(5 \mathrm{WAS})\end{array}$ \\
\hline Without herbicides & $42.10^{\mathrm{g}}$ & $90.92^{\mathrm{ef}}$ & $95.21^{\mathrm{ef}}$ \\
Pendimethalin $\left(750 \mathrm{~g} \mathrm{ha}^{-1}\right)$ & $102.29^{\mathrm{de}}$ & $127.10^{\mathrm{abc}}$ & $120.72^{\mathrm{bcd}}$ \\
Bispyribac $\left(25 \mathrm{~g} \mathrm{ha}^{-1}\right)$ & $77.76^{\mathrm{f}}$ & $104.86^{\text {cde }}$ & $105.40^{\text {cde }}$ \\
Pendimethalin $\left(750 \mathrm{~g} \mathrm{ha}^{-1}\right)$ & $133.67^{\mathrm{ab}}$ & $149.24^{\mathrm{a}}$ & $122.49^{\text {bcd }}$ \\
+ Bispyribac $\left(25 \mathrm{~g} \mathrm{ha}^{-1}\right)$ & & & \\
\hline $\begin{array}{l}\text { Means followed by common letters do not differ significantly } \\
\text { at }(p=0.05) \text { level by DMRT }\end{array}$
\end{tabular}

significantly by various $\mathrm{BM}$ treatments. $\mathrm{N}$ content in weeds in BM done at 5 WAS and without BM was at par with each other but significantly higher than BM at 4 WAS. it might be due to less infestation of weeds in this treatment. Among herbicide treatments, unsprayed check was recorded the highest $\mathrm{N}$ content in weeds which was significantly higher than other herbicide treatments followed by bispyribac alone.

The data of nitrogen uptake of paddy grain as presented in Table 6 revealed that nitrogen uptake in paddy grains was influenced significantly by different brown manuring treatments and it varied from 40.12 to $56.22 \mathrm{~kg} \mathrm{ha}^{-1}$. Nitrogen uptake was highest in rice+BM (4 WAS) followed by rice+BM ( 5 WAS). Among herbicide treatments, pendimethalin fb bispyribac sodium recorded significantly higher nitrogen uptake as compared to pendimethalin and bispyribac sodium alone. The range of numerical values ranged from 29.86 to $66.90 \mathrm{~kg} \mathrm{ha}^{-1}$. The interaction effect of different BM and herbicidal treatments was also found to be significant. Rice+BM (4 WAS) with pendimethalin $\mathrm{fb}$ bispyribac sodium recorded significantly 
Table 6: Interaction effect of brown manuring (BM) and herbicide treatments on $\mathrm{N}$ uptake of grain and straw $\left(\mathrm{kg} \mathrm{ha}^{-1}\right)$ in direct seeded rice

\begin{tabular}{|c|c|c|c|c|c|c|}
\hline \multirow[t]{2}{*}{ Treatment } & \multicolumn{3}{|c|}{ Nitrogen uptake in Grain } & \multicolumn{3}{|c|}{ Nitrogen uptake in Straw } \\
\hline & $\begin{array}{l}\text { Rice } \\
\text { sole }\end{array}$ & $\begin{array}{l}\text { Rice+BM } \\
\text { (4 WAS) }\end{array}$ & $\begin{array}{l}\text { Rice+BM } \\
\text { (5 WAS) }\end{array}$ & $\begin{array}{l}\text { Rice } \\
\text { sole }\end{array}$ & $\begin{array}{c}\text { Rice+BM } \\
\text { (4 WAS) }\end{array}$ & $\begin{array}{c}\text { Rice+BM } \\
\text { (5 WAS) }\end{array}$ \\
\hline Without herbicides & $15.59^{\mathrm{h}}$ & $35.64^{\mathrm{fg}}$ & $38.37^{\text {efg }}$ & $16.44^{\mathrm{c}}$ & $36.50^{\mathrm{ab}}$ & $34.59^{\mathrm{abc}}$ \\
\hline Pendimethalin $750 \mathrm{~g} \mathrm{ha}^{-1}$ & $44.30^{\operatorname{defg}}$ & $63.81^{\mathrm{abc}}$ & $53.66^{\text {bcde }}$ & $43.45^{\mathrm{ab}}$ & $48.39^{\mathrm{ab}}$ & $49.21^{\mathrm{ab}}$ \\
\hline Bispyribac $25 \mathrm{~g} \mathrm{ha}^{-1}$ & $32.77^{\mathrm{g}}$ & $49.97^{\text {cdef }}$ & $42.71^{\text {defg }}$ & $31.30^{\mathrm{bc}}$ & $36.18^{\mathrm{ab}}$ & $43.58^{\mathrm{ab}}$ \\
\hline $\begin{array}{l}\text { Pendimethalin } 750 \mathrm{~g} \mathrm{ha}^{-1} \mathrm{fb} \\
\text { Bispyribac } 25 \mathrm{~g} \mathrm{ha}^{-1}\end{array}$ & $67.82^{\mathrm{ab}}$ & $75.48^{\mathrm{a}}$ & $57.42^{\mathrm{bcd}}$ & $49.82^{\mathrm{ab}}$ & $52.04^{\mathrm{a}}$ & $50.52^{\mathrm{ab}}$ \\
\hline
\end{tabular}

Means followed by common letters do not differ significantly at $(p=0.05)$ level by DMRT

higher nitrogen uptake as compared to other treatment combinations.

Different brown manuring treatments have significant effect on nitrogen uptake by paddy straw (Table 7). It can be concluded

Table 7: Interaction effect of brown manuring (BM) and herbicide treatments on $\mathrm{N}$ uptake of weeds $\left(\mathrm{kg} \mathrm{ha}^{-1}\right)$ in direct seeded rice

\begin{tabular}{lccc}
\hline Treatment & $\begin{array}{c}\text { Rice } \\
\text { sole }\end{array}$ & $\begin{array}{c}\text { Rice+BM } \\
(4 \mathrm{WAS})\end{array}$ & $\begin{array}{c}\text { Rice+BM } \\
(5 \mathrm{WAS})\end{array}$ \\
\hline Without herbicides & $88.55^{\mathrm{a}}$ & $23.68^{\mathrm{cd}}$ & $18.08^{\mathrm{de}}$ \\
Pendimethalin $\left(750 \mathrm{~g} \mathrm{ha}^{-1}\right)$ & $31.84^{\mathrm{bc}}$ & $12.00^{\mathrm{ef}}$ & $17.62^{\mathrm{de}}$ \\
Bispyribac $\left(25 \mathrm{~g} \mathrm{ha}^{-1}\right)$ & $35.25^{\mathrm{b}}$ & $13.19^{\mathrm{ef}}$ & $11.94^{\mathrm{ef}}$ \\
Pendimethalin $\left(750 \mathrm{~g} \mathrm{ha}^{\mathrm{fg}}\right.$ & $7.00^{\mathrm{fg}}$ & $1.87^{\mathrm{g}}$ & $4.50^{\mathrm{fg}}$ \\
$\left.{ }^{-1}\right)+$ Bispyribac $\left(25 \mathrm{~g} \mathrm{ha}^{-1}\right)$ & & & \\
\hline
\end{tabular}

Means followed by common letters do not differ significantly at $(p=0.05)$ level by DMRT

from the data that Rice+BM (4 WAS) recorded highest uptake of nitrogen by straw which was at par with rice+BM (5 WAS). However, herbicide treatments influenced the nitrogen uptake of paddy straw. $\mathrm{N}$ uptake by straw in pendimethalin $\mathrm{fb}$ bispyribac sodium and pendimethalin alone were statistically at par with each other but significantly higher than bispyribac alone and unsprayed check. $N$ uptake by straw was significantly higher with rice+BM (4 WAS) in pendimethalin fb bispyribac which was significantly higher than all combinations of BM with herbicide treatments. The data revealed that nitrogen uptake by weeds was also affected significantly by various BM treatments. $\mathrm{N}$ uptake by weeds in BM done at 5 WAS and without BM was at par with each other but significantly higher than BM at 4 WAS. It might be due to less infestation of weeds in this treatment.

Among herbicide treatments, unsprayed check recorded the highest $\mathrm{N}$ uptake of weeds which was significantly higher than other herbicide treatments followed by bispyribac alone.
$\mathrm{N}$ uptake by weeds was significantly higher in sole rice under unsprayed check as compared to all other treatment combinations. The $\mathrm{N}$ uptake was negatively correlated with total weed dry matter (Figure 1) which was the highest under the treatment combination of rice+BM (4 WAS) and pendimethalin and bispyribac herbicide. The total weed dry matter explained $74 \%$ variation in $\mathrm{N}$ uptake (Figure 1).

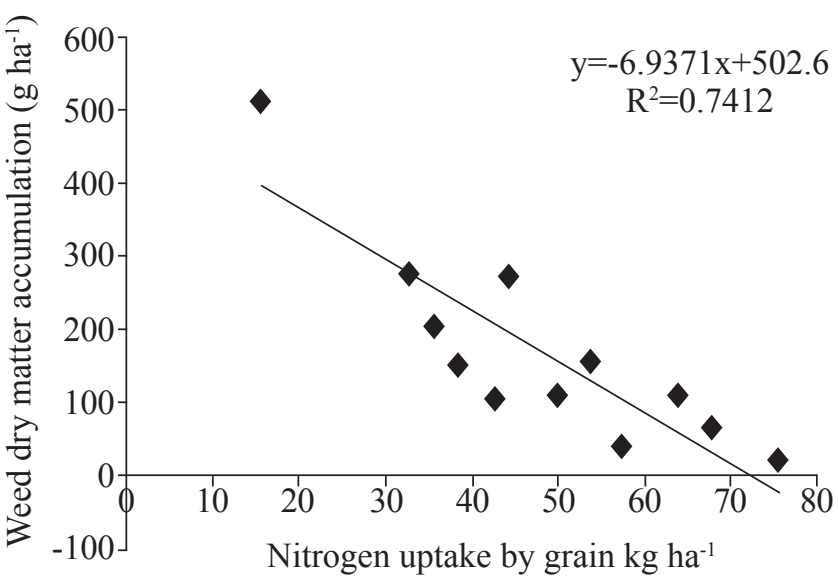

Figure 1: Correlation between weed dry matter accumulation and nitrogen uptake by grain

\section{Conclusion}

Rice + Sesbania (BM of Sesbania at 4 WAS) and rice + Sesbania (BM of Sesbania at 5 WAS) reduced weed density and dry matter in DSR compared to rice without BM. Rice+BM (4 WAS) with pendimethalin $750 \mathrm{~g} \mathrm{ha}^{-1} \mathrm{fb}$ bispyribac $25 \mathrm{~g} \mathrm{ha}^{-1}$ recorded significantly higher nitrogen uptake by grain and straw compared to other treatment combinations. $N$ uptake by weeds was significantly higher in sole rice under unsprayed check.

\section{References}

Anonymous, 2016. Agricultural Statistics at a Glance, 2015. Directorate of Economics and Statistics, Department of Agriculture, Cooperation and Farmers Welfare, Ministry 
of Agriculture \& Farmers Welfare, Govt. of India, 84. PAU, 2016. Package of Practices for kharifCrops. Punjab Agricultural University, Ludhiana.

Anwar, M.P., Juraimi, A.S., Puteh, A., Selamat, A., Rahman, M.M., Samedani, M., 2012. Seed priming influences weed competitiveness and productivity of aerobic rice. Acta Agriulturae Scandinavica 62, 499-509.

Blackshaw, R.E., 2003. Model of rice yield reduction as a function of weed interference. Weed Science 51, 532-539.

Blackshaw, R.E., Moyer, J.R., Harker, K.N., Clayton, G.W., 2005. Integration of agronomic practices and herbicides for sustainable weed management in a zero-till barley field pea rotation. Weed Technology 19, 190-196.

Chauhan, B.S., Johnson, D.E., 2011. Row spacing and weed control timing affect yield of aerobic rice. Field Crops Research 121, 226-231.

Das, T.K., Yaduraju, N.T., 1996. Crop-weed competition studies in some Kharif crops. I: Physiological parameters. Indian Journal of Agricultural Research 30, 235-241.

Davidson, E.A., 1991. Fluxes of nitrous oxide and nitric oxide from terrestrial ecosystems. In Rogers, J.E., and Whittman, W.B., (eds.) Microbial Production and Consumption of Greenhouse Gases: Methane, Nitrogen Oxides and Halo-methanes. American Society for Microbiology, 219-235.

Fageria, N.K., Baligar, V.C., 2005. Enhancing nitrogen use efficiency in crop plants. Advances in Agronomy 88, 97-185.
Gaire, R., Dahal, K.R., Amgain, L.P., 2013. Effect of different mulching materials on weed dynamics and yield of direct seeded rice in Chitwan, Nepal. Agronomy Journal of Nepal 3, 73-81.

Jayadeva, H.M., Bhairappanavar, S.T., Hugar, A.Y., Rangaswamy, B.R., Mallikarjun, G.B., Malleshappa, C., Naik, C.D., 2011. Integrated Weed management in Aerobic Rice (Oryza sativa L.). Agriculture Science Digest 31, 58-61.

Mahajan, G., Chauhan, B.S., 2013. The role of cultivars in managing weeds in dry-seeded rice production systems. African Journal of Biotechnology 10, 15259-15271.

Maity, S.K., Mukherjee, P.K., 2008. Integrated weed management in dry direct seeded rainy season rice (Oryza sativa L.). Indian Journal of Agronomy 53, 116-120.

Mckenzie, H.A., Wallace, H.S., 1964. The Kjeldahl determination of Nitrogen: A critical study of digestion conditions-Temperature, Catalyst, and Oxidizing agent. Australian Journal of Chemistry 7, 55-70.

Sunil, C.M., Shekara, B.G., Kalyanmurthy, K.N., Shankaralingapa, B.C., 2010. Growth and yield of aerobic rice as influenced by integrated weed management practices. Indian Journal of Weed Science 42, 180-183.

Tripathi, J., Bhatta, M.R., Justice, S., Sakya, N.K., 2004. Direct seeding-An emerging resource conserving technology for rice cultivation in rice- wheat system. Gautam, A.K., Akhtar, T., Chaudhary, B., Gaireb, J., Bhatta, K.R. (eds) In: Proceedings of $24^{\text {th }}$ Rice Research in Nepal summer crop workshop, Dhanusha., 273-281. 